\title{
Ecological Footprint Analysis:Case of Xiushan County Weijun $\mathrm{He}^{1, \mathrm{a}}$ Jun $\mathrm{Wu}^{2, \mathrm{~b}}$ Hui Zhang ${ }^{3, \mathrm{c}}$ \\ 1,2,3 School of Three Gorges University ,Yichang 443002,China; a78005803@qq.com, b1040102873@qq.com, '516330896@qq.com
}

Keywords: Ecological Footprint, Ecological carrying capacity Ecological Benefits.

\begin{abstract}
Protecting the ecological environment of Wuling Mountain Area is important for realization sustainable development in the area. This study, using the ecological foot print model calculated the ecological footprint and ecological capacity of the XiuShan county. According to the analysis the results for the year 2011 were $2.3719 \mathrm{hm}^{2}, 0.5830 \mathrm{hm}^{2}$ and $-1.7889 \mathrm{hm}^{2}$ for per capita ecological footprint, per capita ecological carrying capacity, capita ecological deficit of the area respectively .Based on these results XiuShanXian monetization ecological footprint was found to be -68 one hundred million. This shows the local ecological environment is under serious deficit. Finally this paper recommended course of actions that need to be taken in order to integrate the economic development with the environmental protection for realization of sustainable development in the area.
\end{abstract}

\section{Introduction}

Combing the economic development and environmental protection by realizing sustainable development is the key for the regional development and poverty alleviation. Wuling Mountain Area is among national minority areas which are the focus of poverty alleviation and sustainable development plans by the government, Xiushan County is one of the counties in the area. In the past various studies developed models for calculating the ecological foot print.one of the model is developed in the early 1990s by the Canadian ecological economist William Rees who was first to propose a model that can be used to measure the ecological footprint of human activities on natural resources. His model uses the ecological carrying capacity to measure the supply of natural resources and then use the supply and consumption to measure the sustainable development of the region. ${ }^{[1]}$

Scholars are continuously refining the theory in order to develop a method which can provide a more accurate result which can be helpful in the process of integrating the economic development and environmental protection in a more sustainable way.

\section{Research Methods}

Ecological Footprint. ${ }^{[2,3]}$ The ecological foot print model was used to calculate the area's ecological foot print.

Ecological Footprint is calculated as follows:

$$
E F=N^{*} e f=N^{*} r_{j} * \sum a a_{i}=N^{*} r_{j} * \sum\left(\frac{c_{i}}{p_{i}}\right)
$$

Where,

$E F$ is the total ecological footprint;

$N$ is the local population;

ef is ecological footprint per unit;

$r_{j}$ is balancing factor of $\mathrm{j}$-th land;

$a a_{i}$ is the conversion of consumer goods into biologically productive area;

$c_{i}$ is the total consumption of the i-th kinds of consumer goods; 
$p_{i}$ is global total consumption of $\mathrm{i}$-th kind of consumer goods.

Ecological Capacity. ${ }^{[2,3]}$ This paper adopts the calculation of ecological carrying capacity to determine the supply of local ecological footprint. Ecological carrying capacity is calculated as follows:

Where,

$$
\mathrm{EC}=N * \sum c_{j}=N * \sum a_{j}^{*} r_{j} * y_{j}
$$

$E C$ is the total ecological force;

$N$ is the population,

$c_{j}$ is the ecological carrying capacity components per capita,

$a_{j}$ is biologically productive land area per capita of -th ,

$r_{j}$ is balanced factor of $\mathrm{j}$-th kind of land,

$y_{j}$ is the yield factor of $\mathrm{j}$-th kind of land.

Ecological Benefits. ${ }^{[4,5]}$ In the study we monetarized the ecological surplus or deficit basing on the analysis of the ecological carrying capacity, which makes ecological benefit appears more intuitive. The procedure for monetization of the ecological benefit is the following:

The ultimate value of ecological benefit: $\quad V=\left(\mathrm{S}_{\mathrm{f}}-D_{\mathrm{f}}\right) * \mathrm{C}_{\mathrm{Co}_{2}} * \mathrm{p}$

The forest ecological footprint supply : $S_{\mathrm{f}}=\sum s_{j} *\left(\frac{r_{j}}{r_{\mathrm{f}}}\right)$

The forest ecological footprint demand : $\quad D_{f}=N^{*} \sum \frac{C_{j}}{r}$

Where,

$\mathrm{V}$ is an Ecological benefit of monetary value.

$S_{f}$ is the total ecological footprint supply conversing into forest ecological footprint supply.

$D_{f}$ is the total ecological carrying capacity conversing into forest ecological carrying capacity

$C_{\mathrm{co}_{2}}$ is the unit quantity for per hectare forest, $p$ is the unit price for carbon sinks, $r_{f}$ is the equivalence factor.

\section{Results and Discussion}

More comprehensive ecological footprint and ecological capacity Xiushan county were calculated for the year 2011 and the results obtained are account the results obtained are shown in shown in the table below.

Ecological footprint and ecological carrying capacity calculation has been Xiushan county ecological footprint calculation results are shown in Table 1: 
Table 1 Xiushan County, Chongqing Municipality in 2011 ecological footprint calculations

\begin{tabular}{|c|c|c|c|c|c|c|c|}
\hline \multicolumn{4}{|c|}{ Per capita ecological footprint demand } & \multicolumn{4}{|c|}{ Per capita ecological footprint supply } \\
\hline Land types & $\begin{array}{l}\text { Per capita } \\
\text { area }\left(\mathrm{hm}^{2}\right)\end{array}$ & $\begin{array}{l}\text { Equili } \\
\text { brium } \\
\text { factor }\end{array}$ & $\begin{array}{c}\text { Ecological } \\
\text { footprint } \\
\text { required } \\
\left(\mathrm{hm}^{2}\right)\end{array}$ & Land types & $\begin{array}{c}\text { Per capita } \\
\text { area }\left(\mathrm{hm}^{2}\right)\end{array}$ & $\begin{array}{l}\text { Equilibr } \\
\text { ium } \\
\text { factor }\end{array}$ & $\begin{array}{c}\text { Ecological } \\
\text { footprint } \\
\text { required } \\
\left(\mathrm{hm}^{2}\right)\end{array}$ \\
\hline Arable land & 0.1933 & 2.8 & 0.5411 & Arable land & 0.1011 & 1.66 & 0.4700 \\
\hline Lawn & 1.0419 & 0.5 & 0.5210 & Lawn & 0.1739 & 0.19 & 0.1741 \\
\hline Woodland & 0.0038 & 1.1 & 0.0042 & Woodland & 0.1592 & 0.91 & 0.0151 \\
\hline Fossil energy & 1.1645 & 1.1 & 1.2810 & Fossil energy & 0 & 0 & 0 \\
\hline Building land & $1.71 \mathrm{E}-06$ & 0.5 & 0.0000 & Building land & 0.0193 & 0.19 & 0.0018 \\
\hline Waters & 0.1235 & 0.2 & 0.0247 & Waters & 0.0061 & 1.00 & 0.0012 \\
\hline-- & -- & -- & -- & \multicolumn{4}{|c|}{ Biodiversity Conservation(-12\%): 0.0793} \\
\hline \multicolumn{4}{|c|}{ Total ecological demand: 2.3719} & \multicolumn{4}{|c|}{ Total ecological supply: 0.5830} \\
\hline
\end{tabular}

Carbon sequestration value of the ecological footprint is calculated separately. supply and demand was woodland ecological footprint of the preceding conversion of the ecological benefits, the results are as follows:

Table 2 Conversion table for the supply of ecological service and the Demand's ecological footprint on the different land biomes

\begin{tabular}{|c|c|c|c|c|c|c|c|c|}
\hline \multicolumn{4}{|c|}{ Supply of land type conversion table } & \multicolumn{5}{|c|}{ Demand ecological footprint land type conversion table } \\
\hline $\begin{array}{l}\text { Land } \\
\text { types }\end{array}$ & $\begin{array}{l}\text { Equilibri } \\
\text { um } \\
\text { conversi } \\
\text { on factor }\end{array}$ & $\begin{array}{c}\text { The total } \\
\text { area } \\
\left(\mathrm{hm}^{2}\right)\end{array}$ & $\begin{array}{c}\text { Converted } \\
\text { into } \\
\text { wooded } \\
\text { area } \\
\left(\mathrm{hm}^{2}\right)\end{array}$ & $\begin{array}{c}\text { Ecological } \\
\text { footprint } \\
\text { demand } \\
\left(\mathrm{hm}^{2}\right)\end{array}$ & $\begin{array}{l}\text { Equilib } \\
\text { rium } \\
\text { conver } \\
\text { sion } \\
\text { factor }\end{array}$ & $\begin{array}{l}\text { Converted } \\
\text { to forest } \\
\text { ecological } \\
\text { footprint } \\
\text { demand } \\
\left(\mathrm{hm}^{2}\right) \\
\end{array}$ & $\begin{array}{c}\text { Populatio } \\
n\end{array}$ & $\begin{array}{c}\text { The total } \\
\text { area } \\
\text { converted } \\
\text { to forest } \\
\text { land } \\
\left(\mathrm{hm}^{2}\right)\end{array}$ \\
\hline $\begin{array}{c}\text { Arable } \\
\text { land }\end{array}$ & 2.5455 & 65792 & 167470.55 & 0.5642 & 1.1 & 0.5129 & 650600 & 333677.36 \\
\hline $\begin{array}{l}\text { Woodl } \\
\text { and }\end{array}$ & 1.0000 & 113126 & 113126.00 & 0.0042 & 1 & 0.0042 & 650600 & 2705.06 \\
\hline Lawn & 0.4545 & 103600 & 47090.91 & 0.5210 & 1.1 & 0.4736 & 650600 & 308124.16 \\
\hline Waters & 0.1818 & 4000 & 727.27 & 0.0247 & 1.1 & 0.0225 & 650600 & 14608.15 \\
\hline $\begin{array}{l}\text { Land } \\
\text { for } \\
\text { constru } \\
\text { ction }\end{array}$ & 0.4545 & 12557 & 5707.73 & 0 & 1.1 & 0 & 650600 & 0.51 \\
\hline $\begin{array}{l}\text { Fossil } \\
\text { energy }\end{array}$ & - - & - & - - & 1.2810 & 1.1 & 1.1645 & 650600 & 757651.75 \\
\hline Total & -— & -— & 334122.45 & - & - & -— & - & 1416766.98 \\
\hline
\end{tabular}

From the above results,we know that in the Xiushan area :

$$
S_{\mathrm{f}}=334122.45, \quad D_{f}=1416766.98
$$

According to scientific research shows that: forest carbon density is 79 tonnes $\mathrm{C} /$ hectare, Per hectare of forest can absorb 79 tons of carbon sequestration. Accounting in accordance with the best prices Zhang Ying et al. (2010) ${ }^{[5]}$ estimated the forest carbon sinks to $\$ 10.11 \sim 15.17$ / ton (here in averaging), ecological benefits monetary value calculated Xiushan county is:

$$
V=(334122.45-1416766.98) * 79 *(10.11+15.17) / 2=-1081085520 \text { Dollar }
$$


It the results show that ,XiuShanXian ecological deficit reached more than $\$ 1$ billion, The average interest rate based on the year of 6.313 yuan against the dollar, Equivalent to approximately RMB 6.8 billion, which Xiushan county year ecological benefits monetary value of -68 billion.

The results of the study depicts that the county's ecological deficit is very high and needs immediate action to be taken to correct the situation to make the sustainable development of the region a reality in the very near future.

\section{Conclusions and Recommendations}

The results showed that ecological deficit is quite serious in the area. The local government should pay attention to local ecological environment, and reduce the region's ecological deficit of the area. Meanwhile, government should take effective measures for the sustainable development of local economy and the environment. The authors recommend the following three important points:

- Improving the utilizable rate of fossil fuels, especially coal resources.

- Developing low-carbon economy and promoting the development of carbon sequestration market.

- Supporting the construction of the local ecological environment protection system and enhancing environmental awareness in the area.

\section{Acknowledgments}

Funding for this research was provided through the National Social Science Fund (No.13BMZ057). The authors would like express their gratitude for the support. The authors also would like to thank Dagmawi Mulugeta Degefu,Shen Changgeng,Cai Yanwei and for their assistance during the course of the research.

\section{References:}

[1]Ree W E.Ecological footprint and appropriated carrying capacity:what urban economics leaves out,J.Environment and Urbanization,04(1992)2.

[2]Wang Shu-hua, MaoHanying, Wang Zhongjing,Recent research progress of ecological footprint,J. Natural Resources, 06(2002)776-782.

[3]LuYuan,HuaCui,Guangxi1990-2002Dynamicanalysis of ecological footprint,J.China Population, Resources and Environment, 03(2004)51-55.

[4] Li Shunlong. Study of forest carbon sinks economic problems,D.Northeast Forestry University, 2005.

[5] Zhang Ying, Wu Lili, Su Fan, Yang Zhigeng.Accounting of forest carbon sinks Research Model,J. Beijing Forestry University, 02(2010)194-200.

[6] Fan Yibin,Zong Gang.Alpine grassland ecological sanctuary on ecological footprint analysis - A Case Study of Champlain County ,J. ecological economy, 2013.

[7] Information on http://xs.cq.gov.cn 